\title{
Commercial antimicrobials mouthrinses on caries and periodontitis-related biofilm control: a review of literature
}

Enxaguatórios comerciais antimicrobianos sobre o controle do biofilme relacionado à cárie dentária e à doença periodontal- uma revisão de literatura

Aline Silva BRAGA ${ }^{1}$, Juliana Gonçalves PIRES ${ }^{1}$, Ana Carolina MAGALHÃES ${ }^{1}$

1- Department of Biological Sciences - Bauru School of Dentistry - University of São Paulo - Bauru - SP - Brazil.

\begin{abstract}
This review aims to discuss the antimicrobial potential of different mouthrinses in respect to the control of dental caries and periodontal disease. The survey was conducted using PubMed and the following keywords: "antimicrobial agent" or "antiplaque agent", "dental biofilm" and "dental caries" or "periodontal disease" or "gingivitis". Only studies published in English, from 2011 to 2015, in journals with impact factor greater than 0.8 , were selected. We found a total of 22 papers, 13 related to dental caries and 9 related to periodontal disease. Among the 13 studies involving cariogenic bacteria and/or biofilm, 6 were conducted in vitro, 3 in situ and 4 in vivo. Among 9 studies involving periodontal disease, 2 were in vitro and 7 in vivo. The main active agents tested were: CHX-Chlorhexidine, CPC-cetylpyridinium chloride and EO-Essential oils (alcohol/or alcohol-free). CHX was compared to EO in 6 studies, showing superiority in 3 studies, similarity in 1 study and inferiority in 2 studies. CPC has shown lower effect in plaque reduction compared to CHX and EO. There is still controversy about the effect of alcohol, but some studies have shown superiority for EO and CHX with alcohol on cariogenic and periodontopathogenic biofilms, respectively, when compared to alcohol-free version; for CPC, no difference was found. More clinical studies are needed for better understanding the mechanism of action and the differences in performance among the antiplaque agents.
\end{abstract}

\section{KEYWORDS}

Antimicrobial agents; Dental biofilm; Dental caries; Oral diseases; Periodontitis.

\section{RESUIMO}

Esta revisão tem como objetivo discutir o potencial antimicrobiano de diferentes enxaguatórios bucais em relação ao controle da cárie dentária e doença periodontal. A pesquisa foi realizada usando PubMed e as seguintes palavras-chave: "agente antimicrobiano" ou "agente antiplaca", "biofilme dental" e "cárie dentária" ou "doença periodontal" ou "gengivite". Foram selecionados os estudos publicados em inglês, de 2011 a 2015, em revistas com fator de impacto maior que 0,8 . Foram encontrados no total 22 artigos, 13 relacionados à cárie dentária e 9 relacionados à doença periodontal. Entre os 13 estudos envolvendo bactérias e/ou biofilme cariogênicos, 6 foram realizados in vitro, 3 in situ e 4 in vivo. Entre os 9 estudos envolvendo doença periodontal, 2 foram in vitro e 7 in vivo. Os principais agentes ativos testados foram: CHX-Clorexidina, CPC-cloreto de cetilpiridínio e OE-óleos essenciais (com álcool ou sem álcool). A CHX foi comparada ao OE em 6 estudos, mostrando superioridade em 3 estudos, similaridade em 1 estudo e inferioridade em 2 estudos. CPC mostrou menor efeito na redução da placa em comparação à $\mathrm{CHX}$ e ao $\mathrm{OE}$. Ainda há controvérsias sobre o efeito do álcool, mas alguns estudos têm mostrado superioridade no caso de OE e CHX com álcool sobre biofilmes cariogênicos e periodontopatogênicos, respectivamente, quando comparados à versão sem álcool; para o CPC, não foi encontrada diferença. Mais estudos clínicos são necessários para melhor compreensão sobre mecanismo de ação e as diferenças de desempenho entre os agentes antiplaca.

\section{PALAVRAS-CHAVE}

Agentes antimicrobianos; Biofilme dental; Cárie dentária; Doenças orais; Periodontite. 


\section{INTRODUCTION}

$\mathrm{T}$ he oral cavity is directly in contact with microorganisms [1]. Saliva, gingival fluid and our diet supply nutrients for them, making the environment propitious to microbiota development [2,3] Microbiota can be organized as biofilm that potentially can cause oral diseases as dental caries and periodontitis [4].

Dental caries is one of the most relevant oral chronic diseases caused by microorganisms from different species organized in a supragingival biofilm. The cariogenic microorganisms metabolize sugar, especially sucrose derived from the diet, producing acids that reduce the biofilm $\mathrm{pH}$ and cause tooth decay [4,5]. The main cariogenic microorganisms present in biofilm are S. mutans, Lactobacillus, bifidobacteria and fungi. S. mutans, in particular, produce insoluble extracellular polysaccharides from sucrose in the biofilm matrix, increasing metabolic efficiency and protecting themselves against host defenses mechanisms $[4,6]$.

On the other hand, subgingival biofilm rich in anaerobic and gram-negative bacteria (A. actinomycetemcomitans, T. forsythia, Campylobacter spp., Capnocytophaga spp., $E$. corrodens, F. nucleatum, $P$. gingivalis, $P$. intermedia) is related to periodontal disease, a common cause of tooth loss in adults [7].

The mechanical disorganization of dental biofilm by toothbrushing is extremely important to prevent dental caries [8] and gingivitis [9], but sometimes insufficient for patients who have unfavorable conditions as, for example, xerostomia [10] and using fixed orthodontic appliances. The use of antimicrobials agents may be an alternative for those patients at high risk of dental caries [10] and periodontal disease $[11,12]$

Among the active agents, chlorhexidine digluconate (CHX), Cetylpyridinium Chloride (CPC) and essential oils (EO) [13] are the most used by the population, who applied them for halitosis control [14]. CHX is considered a gold-standard antimicrobial agent applied in patients with periodontal diseases. It has been indicated as a temporary coadjutant to regular oral hygiene procedures, as a preoperative and/ or postoperative rinse either [15].

Despite the popularity of the antimicrobial agents often found in supermarkets, there is sparse information about their efficacy on the control of oral diseases. Therefore, the aim of this review was to compile information about the efficacy of the main commercial antimicrobial agents applied to prevent tooth decay and periodontal disease.

\section{REVIEW OF LITERATURE}

The survey was conducted using PubMed and the following keywords: "antimicrobial agent" or "antiplaque agent", "dental biofilm" and "dental caries" or "periodontal disease" or "gingivitis". Only studies published in English, from 2011 to 2015, in journals with impact factor greater than 0.8 , were selected. We found a total of 22 papers, 13 related to dental caries and 9 related to periodontal disease, involving in vitro, in situ and in vivo models.

\section{Commercial Agents and Biofilm/Dental Caries}

Chlorhexidine (CHX) is considered a gold standard antimicrobial agent applied in dentistry. Accordingly, most studies testing new antimicrobial agents have included CHX as a positive control. Cetylpyridinium chloride (CPC), also a cationic agent as chlorhexidine, is indicated to combat dental plaque and halitosis [16]. Essential oil (EO: eucalyptol, thymol, salicylate and menthol), a non-ionic agent, is other agent popularly applied to control dental plaque [17]. The agents are mostly available as mouthrinses.

Different commercial mouthrinses containing $\mathrm{CHX}$, in concentrations ranged from 0.05 to $0.2 \%$, were compared to EO (formulae with alcohol) and water (negative control) using multispecies biofilms (A. naeslundii, $V$. 
dispar, F. nucleatum, S. mutans, S. oralis and $C$. albicans). The total CFU were determined using Columbia blood agar, and the $S$. mutans and $S$. oralis CFUs were counted using Mitis-Salivarius agar. The treatments were done after 16.5, 24.5, 40.5 , and $48.5 \mathrm{~h}$ of biofilm formation. After a total time of $64.5 \mathrm{~h}$, CFUs were determined for total microorganisms (A. naeslundii, $V$. dispar, F. nucleatum, $S$. mutans, $S$. oralis and $C$. albicans), S. mutans and $S$. oralis. The total CFU numbers were not significant different among the mouthrinses. Biofilm formation was reduced in $7 \log 10$ steps by $0.2 \%$ CHX (formulae with alcohol), and in $3 \log 10$ steps by EO, 0.05\% CHX (formulae with alcohol), and 0.12 and $0.2 \%$ CHX (without alcohol) solutions compared to water [18].

The effect of three commercial mouthrinses (1- 0.12\% CHX plus $0.05 \%$ CPC; 2- $0.12 \%$ CHX; $3-0.2 \%$ zinc chloride with $1.5 \%$ hydrogen peroxide-Zn), on bacteria adherence (S. mutans, S. faecalis, S. gordonii, A. viscosus and Mixed culture) to hydroxyapatite surfaces was evaluated. The $\%$ of viable bacteria adhered to hydroxyapatite ranged from $8-19 \%$ for $\mathrm{CHX}$ plus CPC; $11-17 \%$ for CHX and $79-89 \%$ for $\mathrm{Zn}$. Therefore, both CHX and CHX plus CPC were effective against the tested bacteria, while $\mathrm{Zn}$ was not [19].

Wakamatsu et al. [20] compared the penetration kinetics of four mouthrinses (CHX, $\mathrm{EO}, \mathrm{CPC}$ and isopropylmethylphenol- IPMP) into $S$. mutans biofilm. The penetration velocities were determined by monitoring fluorescence loss between $30 \mathrm{~s}$ and $5 \mathrm{~min}$ exposure. EO showed the best penetration, but within 30 $s$ no mouthrinse had any antiplaque effect. After $30 \mathrm{~s}$, EO induced the highest reduction in CFU number, but not in bacteria detachment compared to the other mouthrinses.

Nanoemulsions prepared with 25\% soybean oil, 1\% CPC and 10\% Triton X-100TRI (NE) were applied on $S$. mutans, L. casei, C. albicans and A. viscosus both isolated and in a mixed-culture. S. mutans and L. casei biofilms were stained using a live/dead kit. MIC and MBC were determined for all microorganisms isolated and in a mixed-culture. The time kinetics was also analyzed for all microorganisms (1, 5, 15,30 and $60 \mathrm{~min}$ ) using optical density. The adherence of microorganism on glass plates (24 $\mathrm{h}$ ) and the growth of biofilm ( $72 \mathrm{~h}$ ) were analyzed after fixing and staining, using optical density. NE has shown reduced in 83\% the viability of $S$. mutans and $L$. casei biofilm compared to negative control. MIC and MBC of NE were 9- to 27- fold smaller than those from CHX (positive control). In respect to killing curves, NE had a faster and powerful effect compared to CHX. The level of adhesion on glass surface was reduced by 94.2 to $99.5 \%$ in NE treated groups compared to positive (CHX) and negative controls. The antiadherence and anti-biofilm effects of NE suggest a promising anti-caries action [21].

Commercial rinses containing $0.05 \%$ CPC, alcohol or free-alcohol, were compared with $0.05 \%$ fluoride mouthwash $(\mathrm{F})$ and $0.12 \%$ chlorhexidine (positive control-CHX). MIC was firstly determined for each mouthrinse considering 25 microorganism species associated with oral diseases. The second part of the study evaluated the antimicrobial activity using supragingival biofilm collected from 15 subjects, which was exposed ex vivo to the mouthrinses for 5-7 days in anaerobic environment. MIC values were significantly lower for both CPC rinses compared to fluoride rinse especially against gram-negative bacteria (most involved in halitosis etiology), showing a broad-spectrum activity. CHX had the greatest antimicrobial effect. This ex vivo model showed no difference between CPC rinses formulated with alcohol or without alcohol. Both CPC (>90\% killing) and CHX (98\% killing) showed higher antimicrobial activity compared to F [22].

The effect of antimicrobial mouthrinses was also studied in adult patients under orthodontic treatment. The patients were treated with $0.1 \%$ CHX alcohol-free, essential oil (alcohol/alcohol-free) or negative control 
(1\% hydroalcoholic solution) for 4 days (1x30s/ day). Supragingival biofilm and microorganism on tongue were collected and analyzed for UFC counting (S. mutans). All mouthrinses were similarly able to significantly reduce the number of $S$. mutans colonies compared to control for both samples (tongue and biofilm) [23].

The antiplaque effect of EO with or without alcohol was compared in vivo. Thirty subjects were divided into two groups (EO with and without alcohol). They rinsed twice a day for 3 days. EO with alcohol showed better plaque inhibitory effect (plaque index of 2.18 in whole mouth) than alcohol-free solution (plaque index of 2.46) [24].

Oyanagi [25] compared 0.05\% CHX, 0.2\% benzethonium chloride, EO (0.09\% 1.8-cineol, 0.06\% thymol, 0.05\% Methyl salicylate, 0.04\% 1-Menthol and 27\% Ethanol), 7\% povidone iodine (PVP-I) and PBS (negative control) using planktonic cariogenic bacteria (S. mutans/ $S$. sobrinus) and biofilm models. Additionally, two mouthrinses (CHX and EO) were evaluated using biofilm-induced caries and a secondary caries model. EO and PVP-I were the best treatments in reducing the cells viability and CFU counts in planktonic culture and biofilm (especially in top and middle layer). EO further had the best inhibitory effect on the progression of demineralization, showing potential to prevent dental caries.

Albertsson et al. [26] evaluated the antimicrobial effect of EO and CHX alcohol-free mouthrinses on $S$. mutans and Lactobacillus in saliva. Twenty healthy volunteers applied the mouthrinses twice times during 16 days after the regular mechanical oral hygiene. Saliva was collected and analyzed for CFU/ml. Only CHX rinse showed a significant reduction in $S$. mutans and Lactobacillus counting, while EO did not have antimicrobial effect.

Two mouthrinses, EO $(0.092 \%$ of eucalyptol, $0.042 \%$ menthol, $0.060 \%$ of methyl salicylate and $0.064 \%$ of thymol) and $0.2 \%$ CHX, were tested on biofilm in situ. Bacterial viability, thickness and covering grade were evaluated after 4 days of applying each of the mouthrinses (2 times x 30s/day). CHX showed $13.2 \%$ and EO $14.7 \%$ of live bacteria. CHX was better in reducing biofilm thickness compared to EO (CHX $6.5 \mu \mathrm{m}$ vs. EO $10.0 \mu \mathrm{m}$ ) and covering grade (CHX $20.0 \%$ vs. EO 54.3\%). CHX showed better antiplaque effect compared to EO [27].

The effect of CPC (concentrations of 0 , $0.025 \%, 0.05 \%, 0.075 \%$, and $0.1 \%$ ), applied twice day for $1 \mathrm{~min}$, during early ( $0 \mathrm{~h}$ to $50 \mathrm{~h}$ ) and mature (48h to $98 \mathrm{~h}$ ) S. mutans biofilm formation, was determined. All CPC concentrations showed complete anti-biofilm activity during early biofilm formation. For old biofilm, the highest CPC concentrations had effect on dry weight, viability and acidogenicity, but they had no effect on water-insoluble extracellular polysaccharides production. Therefore, CPC has inhibitory effect on young $S$. mutans biofilm only [28].

Hannig et al. [29] compared the effect of fluoride solution (100 ppm F as AmF and 150 $\mathrm{ppm} \mathrm{F}$ as $\mathrm{NaF}$ ) to $0.2 \%$ CHX (positive control) on biofilm adherence to enamel and dentin in situ after $8 \mathrm{~h}$ of $1 \mathrm{~min}$-rinse. The bacterial viability and CFU for total microorganism were determined. In the control group, significantly higher amounts of adherent bacteria were detected on dentin $\left(4.8 \times 10^{6} \pm 5.4 \times 10^{6}\right.$ bacteria $\left./ \mathrm{cm}^{2}\right)$ than on enamel $\left(1.2 \times 10^{6} \pm 1.5 \times 10^{6}\right.$ bacteria $\left./ \mathrm{cm}^{2}\right)$. Chlorhexidine significantly reduced the amount of adherent bacteria (dentin: $2.8 \times 10^{5} \pm 3.4 \mathrm{x}$ $10^{5}$ bacteria / $\mathrm{cm}^{2}$; enamel: $4.2 \times 10^{5} \pm 8.7 \times 10^{5}$ bacteria $/ \mathrm{cm}^{2}$ ). Rinses with the fluoride solution also significantly reduced bacterial adherence to dentin $\left(8.1 \times 10^{5} \pm 1.5 \times 10^{6}\right.$ bacteria/ $\left./ \mathrm{cm}^{2}\right)$. The viability was reduced by both chlorhexidine and fluoride. While a significant reduction of bacterial adherence on enamel and dentin was seen for chlorhexidine, $\mathrm{F}$ reduced the bacterial adherence on dentin only.

Rabe et al. [30] compared the antimicrobial effect of $0.1 \% \mathrm{CHX}$ with $0.2 \% \mathrm{NaF}$. Enamel discs were mounted on healing abutments in the premolar region of three subjects for 7 days. After 
this period, the treatment was done for $1 \mathrm{~min}$. Then, the architecture, bacterial viability and total biomass of the biofilm were evaluated using fluorescence methods. The biofilm architecture was similar for both groups, however CHX had effect on the biofilm surface, while F caused cell damage in the middle and deep biofilm layers. Both rinses were able to significantly reduce the bacterial vitality ( $63 \%$ vs. $95 \%$ in control) and the total biomass $\left(6.5 \times 10^{6}\right.$ arbitrary units $/ \mathrm{mm} 2$ for control, $0.82 \times 10^{6}$ arbitrary units $/ \mathrm{mm} 2$ for CHX and $0.87 \times 10^{6}$ arbitrary units $/ \mathrm{mm}^{2}$ for F). Rinse with CHX has antimicrobial effect in the cell/liquid interface at the top of biofilm. NaF, however, is able to penetrate and exert effect in the middle and deep levels of the biofilm.

Some in vitro studies have shown that fluoride reduces the production of lactate and the biomass of $S$. mutans biofilm when applied in high concentrations [31,32], however, other studies have shown no differences in lactate production, $\mathrm{CFU}$ number and $\mathrm{pH}$ drop by the application of fluoride compared to control in $S$. mutans biofilm $[33,34]$. The antimicrobial effect of fluoride is still not a consensus.

Table I summarizes the results found in the above-cited studies. Generally, CHX and EO seem to be the best antimicrobial agents against cariogenic bacteria. Both CHX and EO showed better antimicrobial effect than CPC, while F has limited antimicrobial effect. Few studies have analyzed the impact of these mouthrinses on the prevention of tooth demineralization, which should be the most relevant question to be answered.

Table I - Effect of commercial antimicrobial mouthrinses on dental caries or bacteria caries-related

\begin{tabular}{|c|c|c|c|c|}
\hline Authors & Active component & $\begin{array}{l}\text { Type of microorganism and } \\
\text { model/ treatment }\end{array}$ & Response variable & Results \\
\hline $\begin{array}{l}\text { Guggenheim \& } \\
\text { Meier } \\
\text { [18] }\end{array}$ & 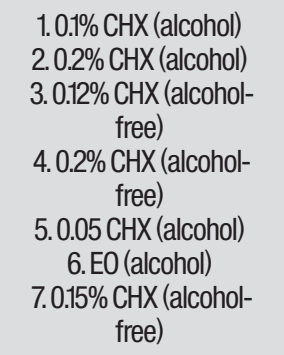 & $\begin{array}{l}\text { Multispecies biofilm/ treatment } \\
\text { of } 1 \text { min each } 12 \mathrm{~h} \text {, during } 64.5-\mathrm{h} \\
\text { in vitro }\end{array}$ & $\begin{array}{l}\text { Total microorganisms (A. naes- } \\
\text { lundii, V. dispar, F. nucleatum, } S \text {. } \\
\text { mutans, S. oralis and C. albicans), } \\
\text { S. mutans and } S . \text { oralisCFU } \\
\text { numbers. }\end{array}$ & $\begin{array}{l}\text { The total CFU numbers did not differ } \\
\text { among the mouthrinses. } \\
0.12 \% \text { CHX (alcohol-free), } 0.2 \% \text { CHX (al- } \\
\text { cohol), } 0.05 \% \text { CHX (alcohol) and Listerine } \\
\text { reduced the number of CFU of } S \text {. mutansin } \\
7 \text { log }^{10} \text { steps compared to control (water). } \\
0.1 \% \text { CHX (alcohol), } 0.2 \% \text { CHX (alcohol), } \\
0.15 \% \text { CHX (alcohol-free) reduced the } \\
\text { number of CFU of } S \text {. orallis in } 3 \text { log go steps } \\
\text { compared to control (water). }\end{array}$ \\
\hline $\begin{array}{l}\text { Marchetti et al. } \\
\text { [24] }\end{array}$ & $\begin{array}{l}\text { 1. EO (alcohol-free) } \\
\text { 2. EO (alcohol) }\end{array}$ & $\begin{array}{c}\text { Cariogenic biofilm/ treatment } \\
\text { twice a day during } 3 \text { days in } \\
\text { vivo }\end{array}$ & Plaque index-Pl in whole mouth & $\begin{array}{l}\text { EO (alcohol) showed better inhibitory effect } \\
\text { compared EO (alcohol-free) }\end{array}$ \\
\hline $\begin{array}{l}\text { Sreenivasan } \\
\text { et al. } \\
\text { [22] }\end{array}$ & $\begin{array}{c}\text { 1.0.05\% CPC+ (alcohol) } \\
2.0 .05 \% \text { CPC- (alcohol- } \\
\text { free) } \\
\text { 3.0.05\% Sodium Fluoride } \\
\text { (alcohol) } \\
\text { 4.0.12\% CHX (alcohol) }\end{array}$ & $\begin{array}{l}\text { (A) } 25 \text { Species associated } \\
\text { with dental caries in planktonic } \\
\text { phase. } \\
\text { (B) Supragingival biofilm collect- } \\
\text { ed from } 15 \text { subjects and treated } \\
\text { with agar media containing } \\
1 \% \text { of each mouthrinse during } \\
5-7 \text { days }\end{array}$ & $\begin{array}{l}\text { MIC and CFU of } S \text {. gordonii, } S \text {. } \\
\text { mutans, C. albicans, A. meyeri, } A \text {. } \\
\text { Viscous. }\end{array}$ & $\begin{array}{l}\text { The cariogenic bacteria were inhibited } \\
\text { by }<6 \% \text { CPC }+ \text { solution, }<3 \% \text { CPC- solu- } \\
\text { tion and }<50 \% \text { F solution. Both CPCs had } \\
\text { similar effect and were better than F. } \\
\text { For CFU, CPC mouthrinses ( }>90 \% \text { killing) } \\
\text { and CHX rinse ( }>98 \% \text { killing) were better } \\
\text { compared to F. }\end{array}$ \\
\hline $\begin{array}{l}\text { Ramalingam } \\
\text { et al. } \\
\text { [21] }\end{array}$ & $\begin{array}{l}\text { 1. } 1 \% \text { CPC and 10\% Triton } \\
\text { X-100-TRI (NE) } \\
\text { 2.0.12\% CHX (alcohol- } \\
\text { free) }\end{array}$ & $\begin{array}{l}\text { S. mutans, L. casei, A. viscosus, } \\
\text { C. albicans and mixed culture } \\
\text { biofilm (72h). }\end{array}$ & $\begin{array}{l}\text { Level of microorganisms adhe- } \\
\text { sion on glass surface and MIC/ } \\
\text { MBC values }\end{array}$ & $\begin{array}{l}\text { MIC and MBC of NE were } 9 \text { - to } 27 \text { - fold } \\
\text { smaller than those from CHX (positive } \\
\text { control). NE has shown reduced in } 83 \% \text { the } \\
\text { viability of } S \text {. mutans and } L \text {. casei biofilm } \\
\text { compared to negative control. The level of } \\
\text { adhesion on glass surface was reduced } \\
\text { by } 94.2 \text { to } 99.5 \% \text { in NE treated groups } \\
\text { compared to positive (CHX) and negative } \\
\text { controls, respectively. }\end{array}$ \\
\hline
\end{tabular}




\begin{tabular}{|c|c|c|c|c|}
\hline Authors & Active component & $\begin{array}{l}\text { Type of microorganism and } \\
\text { model/ treatment }\end{array}$ & Response variable & Results \\
\hline $\begin{array}{l}\text { Oyanagi et al. } \\
\text { [25] }\end{array}$ & $\begin{array}{l}\text { 1.0.05\% CHX (alcohol- } \\
\text { free) } \\
\text { 2.0.2\% benzethonium } \\
\text { chloride } \\
\text { 3. EO (alcohol) } \\
\text { 4.7\% povidone iodine } \\
\text { (PVP-I) }\end{array}$ & $\begin{array}{l}\text { (A) S. mutans and S. sobrinus } \\
\text { in planktonic phase (48-hour } \\
\text { incubation). } \\
\text { (B) Multispecies Biofilm (S. } \\
\text { mutans, } S \text {. sobrinus and } S \text {. } \\
\text { gordonii)/ treatment (1x60s) for } \\
7 \text { days in vitro }\end{array}$ & $\begin{array}{l}\text { CFU counting of cariogenic } \\
\text { bacteria and enamel lesions } \\
\text { analysis. }\end{array}$ & $\begin{array}{l}\text { EO and PVP-I killed more planktonic car- } \\
\text { iogenic bacteria and bacteria embedded } \\
\text { in biofilms compared to PBS, CHX and } \\
\text { benzethonium. } \\
\text { E0 presented the smallest lesions among } \\
\text { the three groups (PBS, CHX and PVP-I) }\end{array}$ \\
\hline $\begin{array}{l}\text { Albertsson et } \\
\text { al. [26] }\end{array}$ & $\begin{array}{l}\text { 1. EO and F } \\
\text { 2. } 0.12 \% \mathrm{CHX} \text { (alcohol- } \\
\text { free) }\end{array}$ & $\begin{array}{l}\text { Inhibition on S. mutans and Lac- } \\
\text { tobacillus in saliva/ treatment } \\
\text { twice a day for } 16 \text { days in vivo }\end{array}$ & CFU counting & $\begin{array}{l}\text { CHX (alcohol-free) showed significant } \\
\text { reduction in S. mutans and Lactobacillus, } \\
\text { while the EO rinse did not. }\end{array}$ \\
\hline $\begin{array}{l}\text { Hanning et al. } \\
\text { [29] }\end{array}$ & $\begin{array}{l}\text { 1.0.2\% CHX (alcohol- } \\
\text { free) } \\
\text { 2. } 100 \text { ppm AmF and } 150 \\
\text { ppm NaF }\end{array}$ & $\begin{array}{l}\text { Biofilm formation (8h) on } \\
\text { enamel and dentin/ treatment } \\
\text { for } 1 \mathrm{~min} \text { in situ }\end{array}$ & Viability and Biofilm adherence & $\begin{array}{l}\text { The viability was reduced by both solu- } \\
\text { tions, while CHX was the only one showing } \\
\text { inhibition of bacterial adherence on both } \\
\text { enamel and dentin. }\end{array}$ \\
\hline $\begin{array}{l}\text { Ulkur et al. } \\
\text { [23] }\end{array}$ & $\begin{array}{l}\text { 1. EO (alcohol) } \\
\text { 2. EO (alcohol-free) } \\
\text { 3. 0.1\% CHX (alco- } \\
\text { hol-free) }\end{array}$ & $\begin{array}{l}\text { Treatment for } 4 \text { days in vivo. } \\
\text { Groups } 1 \text { and } 3 \text { rinsed } 2 \times 30 \text { s/ } \\
\text { day, while Group } 2 \text { rinsed } \\
3 \times 30 \text { s/day }\end{array}$ & $\begin{array}{l}\text { CFUs counting for } S \text {. mutans on } \\
\text { the teeth and tongue surfaces }\end{array}$ & $\begin{array}{l}\text { All mouthrinses were similarly able to sig- } \\
\text { nificantly reduce the number of } S \text {. mutans. }\end{array}$ \\
\hline $\begin{array}{l}\text { Babu and } \\
\text { Garcia-Godoy } \\
\text { [19] }\end{array}$ & 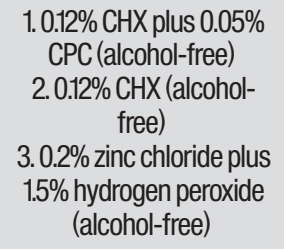 & $\begin{array}{c}\text { S. mutans, S. faecalis, S.gordonii, } \\
\text { A. viscosus in a mixed culture } \\
\text { biofilm }(48 \mathrm{~h}) / \text { treatment during } \\
1 \mathrm{~min} \text { In vitro }\end{array}$ & $\begin{array}{l}\text { Bacterial adhesion, viability and } \\
\text { CFU counts }\end{array}$ & $\begin{array}{l}\text { Both } \mathrm{CHX} \text { and } \mathrm{CHX} \text { plus } \mathrm{CPC} \text { were effective } \\
\text { against the tested bacteria in all assay, } \\
\text { while Zn was not. }\end{array}$ \\
\hline $\begin{array}{l}\text { Wakamatsu et } \\
\text { al. [20] }\end{array}$ & $\begin{array}{c}\text { 1.0.12\% CHX (alcohol- } \\
\text { free) } \\
\text { 2. EO (alcohol) } \\
\text { 3.CPC (alcohol-free) } \\
\text { 4. Isopropyl methyl } \\
\text { phenol } \\
\text { (alcohol-free) }\end{array}$ & $\begin{array}{l}\text { S. mutans biofilm/ treatment } \\
\text { during } 30 \mathrm{~s} \text { in vitro }\end{array}$ & $\begin{array}{l}\text { Penetration velocities and anti- } \\
\text { microbial effect by monitoring } \\
\text { fluorescence loss of calcein } \\
\text { AM-stained biofilms with time- } \\
\text { lapse confocal laser scanning } \\
\text { microscopy. }\end{array}$ & $\begin{array}{l}\text { EO showed the best penetration in biofilm. } \\
\text { None of the mouthrinses have antimicro- } \\
\text { bial effect on S. mutans. }\end{array}$ \\
\hline $\begin{array}{l}\text { Panditetal. } \\
\text { [28] }\end{array}$ & $\begin{array}{l}\text { 1.0.025\% CPC } \\
\text { 2. } 0.05 \% \mathrm{CPC} \\
\text { 3.0.075\% CPC } \\
\text { 4. } 0.1 \% \mathrm{CPC} \\
\text { 5. Negative control } \\
\text { (water). }\end{array}$ & $\begin{array}{l}\text { S. mutans biofilm/ treatment } \\
\text { each } 12 \mathrm{~h} \text {, during } 98 \mathrm{~h} \text { in vitro }\end{array}$ & $\begin{array}{l}\text { Weight, viability and acidoge- } \\
\text { nicity on Early (0h to } 50 \mathrm{~h} \text { ) and } \\
\text { mature (48h to } 98 \mathrm{~h}) \text { S. mutans } \\
\text { biofilm. }\end{array}$ & $\begin{array}{l}\text { In early biofilm all concentrations had anti- } \\
\text { microbial effect. In mature biofilm, only the } \\
\text { highest concentrations of CPC had effect } \\
\text { on dry weight, viability and acidogenicity. }\end{array}$ \\
\hline $\begin{array}{l}\text { Quintas etal. } \\
\text { [27] }\end{array}$ & $\begin{array}{c}\text { 1. EO (alcohol) } \\
\text { 2. } 0.2 \% \text { CHX (alcohol) }\end{array}$ & $\begin{array}{l}\text { Antiplaque effect in situ/ treat- } \\
\text { ment twice a day during } 4 \text { days }\end{array}$ & $\begin{array}{l}\text { Bacterial viability, thickness and } \\
\text { covering grade of dental plaque }\end{array}$ & $\begin{array}{l}\text { CHX and EO presented } 13.2 \% \text { and } 14.7 \% \text { of } \\
\text { live bacteria (ns). } \\
\text { CHX was more efficient in reducing plaque } \\
\text { thickness and covering grade compared } \\
\text { to EO. }\end{array}$ \\
\hline $\begin{array}{l}\text { Rabe etal. } \\
\text { [30] }\end{array}$ & $\begin{array}{l}\text { 1.0.1\% CHX (alcohol-free) } \\
2.0 .2 \% \text { NaF (alcohol- } \\
\text { free) }\end{array}$ & $\begin{array}{l}\text { Cariogenic biofilm in situl } \\
\text { treatment for } 1 \text { min a day during } \\
7 \text { days }\end{array}$ & $\begin{array}{l}\text { Architecture, bacterial viability } \\
\text { and total biofilm biomass }\end{array}$ & $\mathrm{CHX}$ and $\mathrm{NaF}$ caused a similar effect. \\
\hline
\end{tabular}

Abbreviations: $\mathrm{CHX}$ - chlorhexidine; CFU - colony forming units; EO - essential oil; PI - plaque index; CPC - cetylpyridinium chloride; MIC - minimum inhibitory concentration; MBC - minimum bactericidal concentration; NE - Nanoemulsion; PVP-I - Povidone iodine; PBS - Phosphate Buffered Saline; ppm - parts per million; Zn - Zinc chloride; PCA - Pyrrolidone Carboxylic Acid; AM Acetoxymethyl; NaF - Sodium fluoride. 


\section{Commercial Agents and Biofilm/ Periodontal Disease}

CHX, as previously shown, has been widely tested as antiplaque agent. In this in vivo study, the authors tested two formulations. The volunteers rinsed twice a day $0.12 \% \mathrm{CHX}$ (alcohol) or $0.1 \%$ CHX (alcohol-free) with $0.1 \%$ of Formaldehyde (CHX-F) during 7 days. After the treatment, plaque indexes were recorded. The mean plaque of first group $(0.76 \pm 0.38)$ was significantly lower compared to the second group (1.43 \pm 0.56$)$, showing that alcohol might have some influence on the antiplaque effect of CHX [35].

A crossover study was done with ten volunteers using an experimental gingivitis model. The volunteers applied $0.2 \%$ chlorhexidine mouthrinses with alcohol (CHXA) or alcohol-free (CHXNA) for 21 days (2x1min/day). The plaque index (PI), gingival inflammation (GI) and discoloration teeth (DI) were evaluated. Both solutions presented similar PI (CHXA initial $0.55 \pm 0.23$ and final $0.69 \pm$ 0.23 vs. CHXNA initial $0.52 \pm 0.15$ and final $0.75 \pm 0.19$ ), GI (CHXA initial $0.64 \pm 0.32$ and final $0.73 \pm 0.11$ vs. CHXNA initial $0.61 \pm 0.24$ and final $0.77 \pm 0.33$ ), and DI (CHX A initial $0.0 \pm 0.0$ and final $0.20 \pm 0.30$ vs. CHXNA initial $0.0 \pm 0.0$ and final $0.06 \pm 0.06$ ). Therefore, both formulations presented comparable levels of action [36].

Three mouthrinses $(0.12 \%$ chlorhexidine plus $0.05 \%$ CPC; $0.12 \%$ CHX pure and $0.12 \%$ CHX plus NaF) were tested for the inhibition of oral bacteria related with periodontal diseases (S. oralis, A. naeslundii, V. parvula, F. nucleatum, A. actinomycetemcomitans, $P$. gingivalis) and on biofilm formed in vitro. The effect of the mouthrinses was analyzed in bacteria under planktonic phase, which were treated for 1 min using the short interval-killing test. The antimicrobial effect was measured as $\mathrm{CFU} / \mathrm{mL}$ and no difference was found among the rinses. For biofilm formation, the bacteria were grown on sterile ceramic calcium hydroxyapatite
(HAP) discs for $12 \mathrm{~h}$ at $37^{\circ} \mathrm{C}$ using a bioreactor. The discs were immersed in the mouthwash for $2 \mathrm{~min}$ and the biofilm cultivated for 5 days. The viable cells were analyzed using culture methods, scanning electron microscopy (SEM), Live/Dead staining and fluorescence in situ hybridization (CLSM). SEM showed a typical biofilm structure. The fluorescence in situ hybridization technique confirmed the presence of the six bacterial species in biofilms older than 3 days. The live/dead ratio revealed that the majority of cells were alive in 3-, 4- and 5-d biofilms. Cells in biofilms showed more tolerance compared with planktonic cells. In 4-d biofilm, CHX + CPC showed more antimicrobial effect than $\mathrm{CHX}+\mathrm{NaF}$ and $\mathrm{CHX}$ [37].

Both CPC and EO were also compared in an in vivo study, in which 142 subjects wore the mouthrinses for 2 weeks ( $2 \times 30$ s/day). The Modified Gingival Index (MGI), Plaque Index (PI) and bleeding Index (BI) were analyzed. EO demonstrated significant reduction in MGI (9.4\%), PI (6.6\%) and BI (29\%) compared to CPC. EO presented clinical superiority compared to CPC in the short-term management of plaque and gingivitis [38].

Cortelli et al. [11] compared the antiplaque/antigingivitis effect of EO (0.092\% eucalyptol, $0.042 \%$ menthol, $0.060 \%$ methyl salicylate and $0.064 \%$ thymol), $0.07 \%$ CPC and 5\% hydroalcohol solution (control) in 354 healthy volunteers. They were instructed to rinse twice daily (30s each) for 6 consecutive months. The Modified Gingival Index (MGI), Plaque Index (PI) and bleeding Index (BI) were quantified at baseline, after 1,3 and 6 months. After six months, EO (42.0\%) and CPC (13.9\%) demonstrated significant reduction in PI compared to negative control. EO (42.6\%) and CPC (17.1\%) also demonstrated significant reduction in MGI compared to negative control. EO (74.5\%) and CPC (22.8\%) demonstrated significant reduction in BI compared to negative control either. EO presented clinical superiority compared to CPC in the long-term management of plaque and gingivitis. 
$\mathrm{EO}$ (with $\mathrm{ZnCl}_{2}$ and $\mathrm{NaF}$ ) was compared to 0.05\% CPC (NaF) solutions. The subjects applied mouthrinses twice a day (30s) for 6 months. The PI and MGI were analyzed at baseline, after 3 and 6 months. EO mouthrinse showed significant superiority in reducing PI (23.6\%) and MIG (19.5\%) compared to CPC (4.2\% and $1.7 \%)$ mouthrinses after 6 months. In respect to gingivitis, CPC was not different from control after 6 months. EO presented clinical superiority compared to CPC in the long-term management of plaque and gingivitis [39].

Sánchez et al. [40] evaluated the antimicrobial effect of three commercial mouthrinses $(0.12 \%$ CHX plus $0.05 \%$ CPC, $\mathrm{EO}$, and fluoride/stannous fluoride - AFSF) on mixed periodontopathogenic biofilm ( $S$. oralis, $V$. parvula, A. naeslundii, F. nucleatum, $A$. actinomycetemcomitans and $P$. gingivalis) in vitro using ATP bioluminescence and CFU methods. 72h-biofilm was exposed to mouthrinses or control for $1 \mathrm{~min}$. ATP bioluminescence showed antibacterial effect for all mouthrinses compared to PBS control. The lowest cell viability values were found for CHX plus CPC $\left(1.38 \times 10^{8} \pm\right.$ $\left.8.54 \times 10^{7} \mathrm{CFU} / \mathrm{mL}\right)$, followed by AFSF $(1.42 \times 108$ $\left.\pm 9.03 \times 10^{7} \mathrm{CFU} / \mathrm{ml}\right)$, EO $\left(1.67 \times 10^{8} \pm 1.17 \times 10^{8}\right.$ $\mathrm{CFU} / \mathrm{ml})$ and the negative control $\left(2.55 \times 10^{8} \pm\right.$ $\left.1.63 \times 10^{8} \mathrm{CFU} / \mathrm{ml}\right)$. Both $\mathrm{CHX} / \mathrm{CPC}$ and $\mathrm{F}$ were similarly and more effective against biofilm compared to EO.

Commercial mouthrinse with $0.075 \%$ CPC (fluoride-free/alcohol-free) was compared with EO (fluoride-free/alcohol) in respect to antiplaque and antigingivitis effects in vivo. Fluoride-free/alcohol-free mouthwash was used as negative control. After 6 weeks, the subjects from CPC, EO and NC groups exhibited reductions in GI of $28.6 \%, 22.6 \%$ and $1.70 \%$, respectively; while PI was reduced in $31 \%, 28 \%$ and $1.4 \%$ for CPC, EO and NC, respectively. Both mouthrinses provide a significant reduction in dental plaque and gingivitis [41].

A new rinse with CPC (alcohol-free) was tested to control plaque and gingivitis in 67 adults with moderate gingivitis during 6 months (3x30 s/day). PI, bleeding on marginal probing (BOMP) and stain (S) indexes were applied. The presence of $A$. actinomycetemcomitans, $P$. gingivalis, $P$. intermedia/nigrescens, $T$. forsythia, P. micra, Capnocytophaga spp., E. corrodens, Eubacterium spp. and $F$. nucleatum were determined in the biofilm. Significant reduction of the clinical parameters was observed for the tested CPC solution compared to placebo. Among the periodontopathogenic bacteria, $P$. intermedia showed a clear reduction after 3 and 6 months of CPC treatment. CPC shows ability to reduce biofilm accumulation after 3 and 6 months of use [12]

Based mainly on clinical trials as shown in Table II, EO has a superior antiplaque and antigingivitis effects compared to CPC, while EO has a similar efficacy compared to CHX. On the other hand, CHX has often been responsible for inducing undesired effects as tooth discoloration. 
Table II - Effect of commercial antimicrobial mouthrinses on periodontitis/gingivitis or bacteria perio-related.

\begin{tabular}{|c|c|c|c|c|}
\hline Authors & Active component & $\begin{array}{l}\text { Type of microorganism and model/ } \\
\text { treatment }\end{array}$ & Response variable & Results \\
\hline $\begin{array}{c}\text { Charles et al. } \\
\text { [38] }\end{array}$ & $\begin{array}{c}\text { 1. EO (alcohol) } \\
\text { 2. } 0.07 \% \text { CPC (alcohol) }\end{array}$ & $\begin{array}{l}\text { Antiplaque and antigingivitis effects } \\
\text { in vivo. The subjects rinsed with } 20 \mathrm{ml} \\
\text { for } 30 \text { s twice daily during } 2 \text { weeks }\end{array}$ & $\begin{array}{l}\text { Gingival Index-Gl, Plaque } \\
\text { Index-Pl and bleeding } \\
\text { Index-BI }\end{array}$ & $\begin{array}{l}\text { EO demonstrated significant reduction } \\
\text { in Gl, Pland BI compared to CPC. }\end{array}$ \\
\hline $\begin{array}{l}\text { Cortelli etal. } \\
\text { [39] }\end{array}$ & $\begin{array}{c}\text { 1. E0 with zinc chloride } \\
\text { and } 0.02 \% \text { sodium fluoride } \\
\text { (alcohol) } \\
\text { 2.0.05\% CPC +F }\end{array}$ & $\begin{array}{l}\text { Antiplaque and antigingivitis effects } \\
\text { in vivo. The subjects rinsed with } 20 \mathrm{ml} \\
\text { for } 30 \text { s twice daily during } 6 \text { months }\end{array}$ & Gingival and Plaque Index & $\begin{array}{l}\text { E0 presented clinical superiority } \\
\text { compared to CPC. }\end{array}$ \\
\hline $\begin{array}{l}\text { Costa etal. } \\
\text { [12] }\end{array}$ & $\begin{array}{l}\text { 1.0.07\% CPC (alcohol-free) } \\
\text { 2.Saline-based solution } \\
\text { (alcohol-free) }\end{array}$ & $\begin{array}{l}\text { Treatment was done three times a } \\
\text { day, for } 6 \text { months in vivo. }\end{array}$ & $\begin{array}{l}\text { PI, Bl and CFU counts }(A . \\
\text { actinomycetemcomitans, } \\
\text { P. gingivalis, P. intermedial } \\
\text { nigrescens, T. forsythia, } P . \\
\text { micra, Capnocytophaga spp., } \\
\text { E. corrodens, Eubacterium } \\
\text { spp. and F.nucleatum) }\end{array}$ & $\begin{array}{l}\text { Significant reduction of the clinical } \\
\text { parameters was observed for the } \\
\text { tested CPC solution. } \\
\text { P.intermediaCFU showed a clear } \\
\text { reduction after } 3 \text { and } 6 \text { months of CPC } \\
\text { treatment compared to control. }\end{array}$ \\
\hline $\begin{array}{l}\text { Ennibi et al. } \\
\text { [35] }\end{array}$ & $\begin{array}{l}1.0 .12 \% \mathrm{CHX} \text { (alcohol) } \\
2.0 .1 \% \mathrm{CHX} \text { (alcohol- } \\
\text { free) containing 0.1\% } \\
\text { formaldehyde }\end{array}$ & $\begin{array}{l}\text { Antiplaque and antigingivitis effect } \\
\text { for } 7 \text { days in vivo/The treatment was } \\
\text { done twice daily }\end{array}$ & Plaque Indexes & $\begin{array}{l}\mathrm{CHX} \text { with alcohol showed better } \\
\text { inhibition of plaque growth than } \mathrm{CHX} \\
\text { with formaldehyde. }\end{array}$ \\
\hline $\begin{array}{l}\text { Sánchez et al. } \\
\text { [40] }\end{array}$ & $\begin{array}{l}\text { 1. 0.12\% CHX and 0.05\% CPC } \\
\text { (alcohol-free) } \\
\text { 2. EO (alcohol) } \\
\text { 3. } 125 \text { ppm of Amine fluoride } \\
\text { and } 125 \mathrm{ppm} \text { of stannous } \\
\text { fluoride (alcohol-free) - } \\
\text { AFSF }\end{array}$ & $\begin{array}{c}\text { S. oralis, V. parvula, } A \text {. } \\
\text { naeslundii, F. nucleatum, } A \text {. } \\
\text { actinomycetemcomitans in amixed } \\
\text { biofilm (72 hours)/ treatment was } \\
\text { done for } 1 \text { min }\end{array}$ & CFU counting & $\begin{array}{l}\text { CHX/CPC and AFSF containing } \\
\text { mouthrinses demonstrated superior } \\
\text { antimicrobial activity compared to } \\
\text { EO rinse. }\end{array}$ \\
\hline $\begin{array}{l}\text { Blanc et al. } \\
\quad[37]\end{array}$ & $\begin{array}{c}\text { 1.0.12\% CHX plus } 0.05 \% \\
\text { CPC; } \\
\text { 2.0.12\% } \mathrm{CHX} \\
\text { 3.0.12\% CHX plus } \mathrm{NaF}\end{array}$ & $\begin{array}{l}\text { Bacteria related with periodontal } \\
\text { disease in planktonic phase and } \\
\text { multispecies Biofilm in vitro / } \\
\text { treatment was done during } 1 \mathrm{~min} \\
\text { (planktonic) and } 2 \text { min during } 7 \text { days } \\
\text { (biofilm) }\end{array}$ & $\begin{array}{l}\text { CFU counting for periodontal } \\
\text { bacteria }\end{array}$ & $\begin{array}{l}\text { In planktonic phase (S. oralisF. } \\
\text { nucleatum, P. gingivalis and } A \text {. } \\
\text { actinomycetemcomitans)no } \\
\text { differences between the tested } \\
\text { mouthrinses were found. For biofilm, } \\
\mathrm{CHX}+\mathrm{CPC} \text { showed more inhibition } \\
\text { of viable cells compared CHX and } \\
\mathrm{CHX}+\mathrm{NaF} \text {. }\end{array}$ \\
\hline $\begin{array}{l}\text { Cortelli etal. } \\
\text { [11] }\end{array}$ & $\begin{array}{c}\text { 1. EO (alcohol) } \\
\text { 2. } 0.07 \% \text { CPC (alcohol) }\end{array}$ & $\begin{array}{l}\text { Antiplaque and antigingivitis effect } \\
\text { in vivofor } 6 \text { months/treatment was } \\
\text { done twice daily }\end{array}$ & $\begin{array}{c}\text { The MGl,Pl and BI were } \\
\text { quantified after } 1,3 \text { and } 6 \\
\text { months. }\end{array}$ & $\begin{array}{l}\text { EO presented clinical superiority } \\
\text { compared to CPC. }\end{array}$ \\
\hline $\begin{array}{l}\text { Elias-Boneta } \\
\text { et al., } \\
\text { [41] }\end{array}$ & $\begin{array}{l}\text { 1.0.075\% CPC (alcohol-free } \\
\text { and fluoride-free) } \\
\text { 2. EO (alcohol) }\end{array}$ & $\begin{array}{l}\text { The antiplaque and antigingivitis } \\
\text { effect in vivoafter } 6 \text { weeks/ } \\
\text { treatment was done twice daily }\end{array}$ & PlandGl & $\begin{array}{l}\text { Both mouthrinses proved a significant } \\
\text { reduction in dental plaque and } \\
\text { gingivitis. }\end{array}$ \\
\hline $\begin{array}{l}\text { Papaionnou } \\
\text { etal. } \\
\text { [36] }\end{array}$ & $\begin{array}{l}\text { 1.0.2\% CHX (alcohol-free) } \\
\text { 2.0.2\% CHX (alcohol) }\end{array}$ & $\begin{array}{l}\text { The antiplaque and antigingivitis } \\
\text { effect in vivoafter } 21 \text { days/ treatment } \\
\text { was done daily during } 1 \mathrm{~min}\end{array}$ & $\mathrm{Pl}, \mathrm{Gl}$ and Discoloration Index & $\begin{array}{l}\text { Both formulations presented } \\
\text { comparable levels of action. }\end{array}$ \\
\hline
\end{tabular}

Abbreviations: CHX - chlorhexidine; EO - essential oil; CPC - cetylpyridinium chloride; Gl - gingival index; PI - plaque index; BI - bleeding index; F - fluoride; CFU - colony forming units; ppm - parts per million; AFSF - amine fluoride/stannous fluoride; NaF Sodium fluoride; MGl - Modified Gingival Index. 


\section{CONCLUSION}

There are important differences in the antimicrobial performance among the commercial mouthrinses especially considering the bacteria specie (cariogenic vs. periodontopatogenic bacteria). More clinical studies are needed for better understanding the differences in their performance and side effects in short- and long-term studies.

\section{ACKNOWLEDGEMENTS}

The authors thank FAPESP for the concession of scholarship to the first author (2015/11635-2).

\section{REFERENCES}

1. Xu X, He J, Xue J, Wang Y, Li K, Zhang K, et al. Oral cavity contains distinct niches with dynamic microbial communities. Environ Microbiol. 2015;17(3):699-710.

2. Aruni AW, Dou Y, Mishra A, Fletcher HM. The Biofilm Community: Rebels with a Cause. Curr Oral Heal Rep. 2015;2(1):48-56.

3. Jakubovics NS. Saliva as the sole nutritional source in the development of multispecies communities in dental plaque. Microbiol Spectr. 2015;3(3):1-13

4. Marsh PD. Dental plaque as a microbial biofilm. Caries Res. 2004;38:204-11.

5. Keyes PH. The infectious and transmissible nature of experimental dental caries. Findings and implications. Arch Oral Biol. 1960;1(1):304-20.

6. Struzycka I. The oral microbiome in dental caries. Pol J Microbiol. 2014;63(2):127-35.

7. Dye BA. Global periodontal disease epidemiology. Periodontol 2000. 2012;58:10-25.

8. Colak H, Dülgergil CT, Dalli M, Hamidi MM. Early childhood caries update: A review of causes, diagnoses, and treatments. J Nat Sci Biol Med. 2013;4(1):29-38.

9. Spivakovsky S, Keenan A. The effect of anti-plaque agents on gingivitis. Evid Based Dent. 2016;17(2):48-9.

10. Plemons MJ, Al-Hashimi I, Marek LC. Managing xerostomia and salivary gland hypofunction: executive summary of a report from the American Dental Association Council on Scientific Affairs. J Am Dent Assoc. 2014;145(8):867-73.

11. Cortelli SC, Cortelli JR, Shang H, Costa R, Charles CA. Gingival health benefits of essential-oil and cetylpyridinium chloride mouthrinses : a 6 - month randomized clinical study. Am J Dent. 2014;27(3):119-26

12. Costa X, Laguna E, Herrera D, Serrano J, Alonso B, Sanz M. Efficacy of a new mouth rinse formulation based on $0.07 \%$ cetylpyridinium chloride in the control of plaque and gingivitis: A 6-month randomized clinical trial. J Clin Periodontol. 2013:40(11):1007-15.
13. Carvalho MD, Tabchoury CM, Cury JA, Toledo S, Nogueira-Filho GR. Impact of mouthrinses on morning bad breath in healthy subjects. J Clin Periodontol. 2004;31(2):85-90.

14. Tolentino EDS, Chinellato LEM, Tarzia 0. Saliva and tongue coating $\mathrm{pH}$ before and after use of mouthwashes and relationship with parameters of halitosis. J Appl Oral Sci. 2011;19(2):90-4.

15. Varoni E, Tarce M, Lodi G, Carrassi A. Chlorhexidine (CHX) in dentistry: state of the art. Minerva Stomatol. 2012;61(9):399-419.

16. Blom T, Slot DE, Quirynen M, Van der Weijden GA. The effect of mouthrinses on oral malodor: a systematic review. Int J Dent Hyg. 2012;10(3):209-22.

17. Fu J, Wei P, Zhao C, He C, Yan Z, Hua H. In vitro antifungal effect and inhibitory activity on biofilm formation of seven commercia mouthwashes. Oral Dis. 2014;20(8):815-20.

18. Guggenheim B, Meier A. In vitro effect of chlorhexidine mouth rinses on polyspecies biofilms. Schweiz Monatsschr Zahnmed. 2011;121(5):432-41.

19. Babu JP, Garcia-Godoy F. In vitro comparison of commercial oral rinses on bacterial adhesion and their detachment from biofilm formed on hydroxyapatite disks. Oral Health Prev Dent 2014;12(4):365-72.

20. Wakamatsu R, Takenaka S, Ohsumi T, Terao Y, Ohshima H, Okij T. Penetration kinetics of four mouthrinses into Streptococcus mutans biofilms analyzed by direct time-lapse visualization. Clin Oral Investig. 2014;18(2):625-34.

21. Ramalingam K, Amaechi BT, Rawls HR V AL. Antimicrobial Activity of Nanoemulsion on Cariogenic Planktonic and Biofilm Organisms Karthikeyan. Arch Oral Biol. 2012;57(1):15-22.

22. Sreenivasan PK, Haraszthy VI, Zambon JJ. Antimicrobial efficacy of $0 \cdot 05 \%$ cetylpyridinium chloride mouthrinses. Lett Appl Microbiol. 2012;56(1):14-20.

23. Ulkur F, Arun T, Ozdemir F. The effects of three different mouth rinses in a 4-day supragingival plaque regrowth study. Eur J Dent. 2013;7(3):352-8.

24. Marchetti E, Mummolo S, Mattia J Di, Casalena F, Martino S Di, Mattei A, et al. Efficacy of essential oil mouthwash with and without alcohol: a 3-Day plaque accumulation model. Trials. 2011;12(1):1-7.

25. Oyanagi T. Potentials of mouthwashes in disinfecting cariogenic bacteria and biofilms leading to inhibition of caries. Open Dent J. 2012;6:23-30.

26. Albertsson KW, Persson A, Van Dijken JWV. Effect of essential oils containing and alcohol-free chlorhexidine mouthrinses on cariogenic microorganisms in human saliva. Acta Odontol Scand. 2013;71:883-91

27. Quintas V, Prada-López I, Donos N, Suárez-Quintanilla D, Tomás I. Antiplaque effect of essential oils and $0.2 \%$ chlorhexidine on an in situ model of oral biofilm growth: A randomised clinical trial. PLOS One. 2015;10(2):1-18.

28. Pandit S, Cai JN, Jung JE, Lee YS, Jeon JG. Effect of brief cetylpyridinium chloride treatments during early and mature cariogenic biofilm formation. Oral Dis. 2015;21(5):565-71.

29. Hannig C, Gaeding A, Basche S, Richter G, Helbig R, Hannig M Effect of conventional mouthrinses on initial bioadhesion to enamel and dentin in situ. Caries Res. 2013;47(2):150-61. 
30. Rabe P, Twetman S, Kinnby B, Svensäter G, Davies JR. Effect of Fluoride and Chlorhexidine Digluconate Mouthrinses on Plaque Biofilms. Open Dent J. 2015;9:106-11.

31. Takahashi N, Washio J. Metabolomic effects of xylitol and fluoride on plaque biofilm in vivo. J Dent Res. 2011;90(12):1463-8.

32. Liu J, Ling JQ, Zhang K, Huo LJ, Ning Y. Effect of sodium fluoride, ampicillin, and chlorhexidine on Streptococcus mutans biofilm detachment. Antimicrob Agents Chemother. 2012;56(8):4532-5.

33. Zhang M, He LB, Exterkate RAM, Cheng L, Li JY, ten Cate JM, et al. Biofilm layers affect the treatment outcomes of $\mathrm{NaF}$ and nanohydroxyapatite. J Dent Res. 2015;94(4):602-7.

34. Randall JP, Seow WK, Walsh LJ. Antibacterial activity of fluoride compounds and herbal toothpastes on Streptococcus mutans: an in vitro study. Aust Dent J. 2015;60(3):368-74.

35. Ennibi 0, Lakhdar L, Bouziane A, Bensouda Y, Abouqal R. Chlorhexidine alcohol base mouthrinse versus chlorhexidine formaldehyde base mouthrinse efficacy on plaque control: Double blind, randomized clinical trials. Med Oral Patol Oral Cir Bucal. 2013;18(1):135-9.

36. Papaioannou W, Vassilopoulos S, Vrotsos I, Margaritis V, Panis V. A comparison of a new alcohol-free $0.2 \%$ chlorhexidine oral rinse to an established $0.2 \%$ chlorhexidine rinse with alcohol for the control of dental plaque accumulation. Int J Dent Hyg. 2015;(2):1-6.
37. Blanc V, Isabal S, Sánchez MC, Llama-Palacios A, Herrera D, Sanz $\mathrm{M}$, et al. Characterization and application of a flow system for in vitro multispecies oral biofilm formation. J Periodontal Res. 2014;49(3):323-32.

38. Charles CA, McGuire JA, Sharma NC, Qaqish J. Comparative efficacy of two daily use mouthrinses: randomized clinical trial using an experimental gingivitis model. Braz Oral Res. 2011;25(4):338-44.

39. Cortelli SC, Cortelli JR, Wu M-M, Simmons K, Charles CA. Comparative antiplaque and antigingivitis efficacy of a multipurpose essential oil-containing mouthrinse and a cetylpyridinium chloride-containing mouthrinse: a 6-month randomized clinical trial. Quintessence Int. 2012;43(7):82-94.

40. Sánchez MC, Llama-Palacios A, Marín M, Figuero E, León R. Validation of ATP bioluminescence as a tool to assess antimicrobial effects of mouthrinses in an in vitro subgingival-biofilm model. Med Oral Patol Oral Cir Bucal. 2013;18(1):86-92.

41. Elias-Boneta AR, Toro MJ, Noboa J, Romeu FL, Mateo LR, Ahmed $\mathrm{R}$, et al. Efficacy of CPC and essential oils mourhwashes compared to a negative control mouthwash in controlling established dental plaque and gingivitis: a 6 -week, randomized clinical trial. Am J Dent. 2015;28(A):21A-6A.

\section{Ana Carolina Magalhães \\ (Corresponding address)}

Department of Biological Sciences, Bauru School of

Dentistry, University of São Paulo,

Al. Octávio Pinheiro Brisolla 9-75 Bauru, São Paulo, Brazil.

Phone: +551432358497

Date submitted: 2017 Feb 23

E-mail: acm@usp.br 